\title{
Evaluation of Immunomodulatory Parameters in Female Sprague Dawley Rats after Oral Administration of the Biofield Energy Healing Treated Herbomineral Formulation
}

\author{
Mahendra Kumar Trivedi ${ }^{1}$, Alice Branton ${ }^{1}$, Dahryn Trivedi ${ }^{1}$, Gopal Nayak ${ }^{1}$, Aileen Carol Lee ${ }^{1}$, \\ Aksana Hancharuk ${ }^{1}$, Carola Marina Sand ${ }^{1}$, Debra Jane Schnitzer ${ }^{1}$, Rudina Thanasi ${ }^{1}$, \\ Eileen Mary Meagher ${ }^{1}$, Faith Ann Pyka ${ }^{1}$, Gary Richard Gerber ${ }^{1}$, Johanna Catharina Stromsnas ${ }^{1}$, \\ Judith Marian Shapiro', Laura Nelson Streicher ${ }^{1}$, Lorraine Marie Hachfeld", \\ Matthew Charles Hornung ${ }^{1}$, Patricia M. Rowe ${ }^{1}$, Sally Jean Henderson ${ }^{1}$, Sheila Maureen Benson ${ }^{1}$, \\ Shirley Theresa Holmlund ${ }^{1}$, Stephen P. Salters' ${ }^{1}$, Mayank Gangwar ${ }^{2}$, Snehasis Jana ${ }^{2,}$ * \\ ${ }^{1}$ Trivedi Global, Inc., Henderson, USA \\ ${ }^{2}$ Trivedi Science Research Laboratory Pvt. Ltd., Bhopal, India
}

Email address:

publication@trivedieffect.com (S. Jana)

${ }^{*}$ Corresponding author

To cite this article:

Mahendra Kumar Trivedi, Alice Branton, Dahryn Trivedi, Gopal Nayak, Aileen Carol Lee, Aksana Hancharuk, Carola Marina Sand, Debra Jane Schnitzer, Rudina Thanasi, Eileen Mary Meagher, Faith Ann Pyka, Gary Richard Gerber, Johanna Catharina Stromsnas, Judith Marian Shapiro, Laura Nelson Streicher, Lorraine Marie Hachfeld, Matthew Charles Hornung, Patricia M. Rowe, Sally Jean Henderson, Sheila Maureen Benson, Shirley Theresa Holmlund, Stephen P. Salters, Mayank Gangwar, Snehasis Jana. Evaluation of Immunomodulatory Parameters in Female Sprague Dawley Rats after Oral Administration of the Biofield Energy Healing Treated Herbomineral Formulation. American Journal of BioScience. Vol. 5, No. 6, 2017, pp. 104-113. doi: 10.11648/j.ajbio.20170506.12

Received: October 22, 2017; Accepted: November 3, 2017; Published: December 11, 2017

\begin{abstract}
The use of herbomineral formulations for different chronic diseases is gaining popularity because these natural formulations have fewer side effects, a higher safety profile, and more cost effectiveness. A new proprietary herbomineral formulation composed of herbs and certain minerals was formulated, consisting of the herbal root extract ashwagandha and the minerals (zinc, magnesium, and selenium). The aim of the study was to evaluate the immunomodulatory potential of a Biofield Energy Healing (The Trivedi Effect ${ }^{\circledR}$ ) Treatment on the herbomineral formulation in female Sprague Dawley rats. The test formulation was divided into two parts. One part was denoted as the control without any Biofield Energy Treatment, while the other part was defined as the Biofield Energy Treated sample, which received the Biofield Energy Healing Treatment remotely from eighteen renowned Biofield Energy Healers. Immunomodulatory potential, humoral immune response, paw volume, hematological study, biochemistry, body weight, feed intake and histopathology analysis were performed. Humoral immune response data showed increased $(p \leq 0.01)$ primary antibody titre by $124.7 \%$ in the Biofield Treatment test formulation $(\mathrm{G} 3)$, while the untreated test formulation group (G4) showed decreased antibody titre compared with the disease control group (G2). The secondary antibody titre value in the G3 group was also altered compared with the G2 group. Delayed type hypersensitivity (DTH) data suggest that the Biofield Energy Treated test formulation group (G3) showed a significant decrease in paw volume by $128.57 \%$ with respect to the G2 group. Hematology and biochemistry analysis showed altered values, as increased MCHC and RBC count by $138.09 \%$ and $7.24 \%$, respectively in the G3 group compared with the G2 and G4 group. However, the platelet count was increased by $17.70 \%$ in the G3 group compared with the G2 group. The level of blood urea nitrogen was decreased by $10.90 \%$ in the G3 level compared with the G2 group. However, the levels of magnesium and phosphorus were increased by $13.29 \%$ and $6.28 \%$, respectively in the G3 compared with the G2 group. Further, the change in body weight, feed consumption, organ to body weight ratio data, and histopathology examination did not suggest any statistical difference, which depicts that the Biofield Energy Treated test formulations was found to be safe. These data suggest that the Biofield Treated test formulation can be used for autoimmune and inflammatory diseases such as Rheumatoid arthritis, Alzheimer's disease, Atherosclerosis, Dermatitis, Diverticulitis, Diabetes, etc. along with enhancing stress management and
\end{abstract}


anti-aging by improving overall health.

Keywords: Biofield Energy Healing Treatment, Biofield Energy Healers, The Trivedi Effect ${ }^{\circledR}$, Immunomodulation, Herbomineral Formulation, Paw Volume, Autoimmunity, Anti-Aging

\section{Introduction}

Natural products derived from plants and minerals are always regarded as the primary source for new herbomineral formulations for overall health [1]. In developed and developing countries alike, medicinal plant-derived drugs are continuously gaining popularity due to their natural origin and low side effects. Many traditional and complementary medicines are derived from medicinal plants, minerals, and organic matter, which are commonly used for the prevention and treatment of many diseases [2]. According to World Health Organization (WHO), medicinal plants are always the target of most of the pharmaceutical companies for new formulations [3], due to the presence of one or more active phytoconstituents [4]. Hence, the authors of this study used a new proprietary herbomineral formulation with a combination of the herbal root extract ashwagandha and three minerals viz. zinc, magnesium, and selenium as a basis to investigate ways to improve its immunomodulatory activity. Each constituent of the test formulation is reported for important pharmacological activities, such as ashwagandha (Withania somnifera) that belongs to the family Solanaceae, commonly used as alternative therapies $[5,6]$ due to the presence of active molecule like withanolides [7]. Apart from its common attributes such as antibacterial, immunomodulatory and antitumor effects, many clinical and preclinical data have been available with respect to the immunomodulatory impact [8, 9]. The importance of minerals such as selenium, zinc, and magnesium to modulate the immune system has been well-defined [10].

Scientific research has been reported that due to the combination of minerals, herbal medicines have been found to exhibit a high level of phagocytic index and an improved antibody titre [11]. These formulations can be used for better therapeutic effect in immune compromised patients that are affected by cardiovascular diseases, age, stress related diseases, cancer, and autoimmune disorders. Along with the herbomineral formulations, the Biofield Energy Healers in this study have used Energy Medicine (Biofield Energy Healing Treatment) as a complementary and alternative approach to study the impact of the Biofield Energy Treatment on the herbomineral formulation for its immunomodulatory potential in female Sprague Dawley rats.

In recent years, several scientific reports and clinical trials have revealed the useful effects of Biofield Energy Treatments, which has shown enhanced immune function in cases of cervical cancer patients with therapeutic touch [12], massage therapy [13], etc. Complementary and Alternative Medicine (CAM) therapies are now rising as preferred models of treatment, among which Biofield Therapy (or Healing Modalities) is one approach that has been reported to have several benefits to enhance physical, mental and emotional human wellness. The National Center of Complementary and Integrative Health (NCCIH) has recognized and accepted Biofield Energy Healing as a Complementary and Alternative Medicine (CAM) health care approach in addition to other therapies, medicines and practices such as natural products, deep breathing, yoga, Tai Chi, Qi Gong, chiropractic/osteopathic manipulation, meditation, massage, special diets, homeopathy, progressive relaxation, guided imagery, acupressure, acupuncture, relaxation techniques, hypnotherapy, healing touch, movement therapy, pilates, Rolfing structural integration, mindfulness, Ayurvedic medicine, traditional Chinese herbs and medicines, naturopathy, essential oils, aromatherapy, Reiki and cranial sacral therapy. The Human Biofield is a subtle energy that has the capacity to work in an effective manner [14]. Complementary and Alternative Medicine (CAM) therapies have been practiced worldwide with reported clinical benefits in different health disease profiles [15]. This energy can be harnessed and transmitted by individuals into living and non-living things via the process of Biofield Energy Healing. Biofield Energy Treatment (The Trivedi Effect ${ }^{\circledR}$ ) has been published in numerous peerreviewed science journals with significant outcomes in many scientific fields such as cancer research [16, 17], altered antimicrobial sensitivity of pathogenic microbes in microbiology [18-21], genetics [22, 23], altered physical and chemical properties of pharmaceutical compounds [24-27], improved overall growth and yield of plants in agricultural science [28-31], and changing the structure of the atom in relation to various metals, ceramics, polymers and chemicals in materials science [32-35].

The authors of this study want to evaluate the impact of the Biofield Energy Treatment (The Trivedi Effect ${ }^{\mathbb{B}}$ ) on the given herbomineral formulation, which might improve the immunomodulatory function with respect to antibody titre, delayed type hypersensitivity reaction, body weight change, feed consumption, hematological parameters, and serum biochemistry using standard assays.

\section{Material and Methods}

\subsection{Chemicals and Reagents}

Pyrogallol and sodium carboxymethyl cellulose (CMC) were purchased from Sigma Chemical Co. (St. Louis, MO). Withania somnifera (Ashwagandha) root extract powder ( $\geq 5 \%$ of total withanolides) was procured from Sanat Products Ltd., India. Zinc chloride and magnesium (II) gluconate hydrate were procured from TCI, Japan. Sodium selenate was procured from Alfa Aesar, USA. Levamisole 
was procured from Sigma, USA. All other chemicals used in the experiment were of analytical grade available in India.

\subsection{Laboratory Animals}

A total number of 30 healthy female Sprague Dawley rats, weighing between 150-250 grams, were used for the study. The animals were purchased from M/s. Vivo Biotech Ltd., Hyderabad, India for this experiment. Standard normal rodent diet was procured from M/s. Golden feeds, Mehrauli, New Delhi, India and provided ad libitum to all the groups of animals during the experiment under controlled conditions with a temperature of $22 \pm 3^{\circ} \mathrm{C}$, humidity of $30 \%$ to $70 \%$ and a 12 -hour light/12-hour dark cycle. The animals were acclimatized for 5 days prior to the experiment, and all were accessed once daily for clinical signs, behaviors, morbidity and mortality. All the procedures were in strict accordance with the Guide for the Care and Use of Laboratory Animals published by the US National Institutes of Health. The approval of the Institutional Animal Ethics Committee that was obtained prior to carrying out the animal experiment.

\subsection{Biofield Energy Treatment Strategies}

The test formulation was divided into two parts. One part of the test formulation was treated with Biofield Energy by renowned Biofield Energy Healers (also known as The Trivedi Effect ${ }^{\circledR}$ ) and coded as the Biofield Energy Treated formulation, while the second part of the test formulation did not receive any sort of treatment and was defined as the untreated test formulation. This Biofield Energy Treatment was provided through a group of eighteen Biofield Energy Healers who participated in this study and performed the Biofield Energy Treatment remotely. Eleven Biofield Energy Healers were remotely located in the U.S.A, four were remotely located in Canada, two in Finland, and one of which was remotely located in Albania, while the test herbomineral formulation was located in the research laboratory of Dabur Research Foundation, New Delhi, India. This Biofield Energy Treatment was administered for 5 minutes through the Healer's unique Energy Transmission process remotely to the test formulation under laboratory conditions. None of the Biofield Energy Healers in this study visited the laboratory in person, nor had any contact with the herbomineral samples. Further, the control group was treated with a "sham" healer for comparative purposes. The sham healer did not have any knowledge about the Biofield Energy Treatment. After that, the Biofield Energy treated and untreated samples were kept in similar sealed conditions and used for identification of immunological parameters.

\subsection{Antigen (Sheep RBC)}

The fresh sheep blood was collected aseptically from the jugular vein of a healthy sheep and transferred immediately to the heparinized tube. The collected erythrocytes were separated from plasma by centrifugation $\left(400 \mathrm{~g}, 10^{\circ} \mathrm{C}, 10\right.$ minutes), washed twice with the normal saline and then further diluted in saline, which were analyzed using Hematology analyzer (Abbott Model-CD-3700). Based on the number of erythrocytes, the samples were further diluted (using saline) before injecting to the rat [36].

\subsection{Experimental Procedure}

After 5 days of acclimatization, the animals were grouped (G) based on the body weight. G1 (normal control) received oral suspension of $0.5 \%$ carboxy methyl cellulose-sodium salt via gavage. G2 (disease control) group animals received pyrogallol at a dose of $100 \mathrm{mg} / \mathrm{kg}$ through intraperitoneal (i.p.) route once daily for 7 days. G3 group animals received the Biofield Energy Treated test formulation (1105.005 $\mathrm{mg} / \mathrm{kg}$ b.wt, p.o.). G4 group animals received untreated test formulation at the same dose orally, while G5 group animals received levamisole at a dose of $50 \mathrm{mg} / \mathrm{kg}$ p.o. from day 1 to day 22. All the animals except normal control group (G1) received pyrogallol at a dose of $100 \mathrm{mg} / \mathrm{kg}$ through i.p. route once daily from day 1 to day 7 . The animals were treated with the Biofield Energy Treated and untreated herbomineral formulation to the G3 and G4 group animals respectively, 1 hour before pyrogallol challenge in the morning once daily for 22 days. On day $7^{\text {th }}$ and $13^{\text {th }}$, all the animals in G2 to G5 except normal control (G1) were challenged with sheep red blood cells (sRBC) $\left(0.5 \times 10^{9} / 100 \mathrm{gm}\right.$; i.p. $)$, as the antigenic material to sensitize them for immunological parameters. On day $13^{\text {th }}$ and $20^{\text {th }}$, blood was collected from retro-orbital plexus and subjected to hemagglutination test to evaluate the humoral immune response. On same day $20^{\text {th }}$, the animals were challenged with sheep $\operatorname{RBC}\left(0.5 \times 10^{9}\right.$ cells $\left./ 50 \mu \mathrm{L} / \mathrm{rat}\right)$ in sub-planter region and on $22^{\text {nd }}$ ( 48 hours) day, paw volume was measured to evaluate the cellular immune response. The treatment was continued to all the tested groups (G1 to G5) with $5 \mathrm{~mL} / \mathrm{kg}$ body weight as dose volume. The body weight and food consumption were measured daily before treatment. On day 22, the animals were kept under fasting overnight, while on day $23^{\text {rd }}$ blood was collected again from the retroorbital plexus from each animal under anaesthetic condition using isoflurane. Whole blood was analysed for haematological parameters and the serum was analysed for biochemistry parameters. At the end of the study, animals were euthanized by $\mathrm{CO}_{2}$ asphyxiation as per in-house approved standard protocol. Different organs of all animals were excised, weighed and preserved for histopathological analysis.

\subsection{Determination of Humoral Immune Response}

Approximately $25 \mu \mathrm{L}$ of serum was serially diluted with the $25 \mu \mathrm{L}$ of phosphate-buffered saline. The sRBC $(0.025 \mathrm{x}$ $10^{9}$ cells) was added to each of these dilutions and incubated at $37^{\circ} \mathrm{C}$ for 1 hour. The rank of minimum dilution that exhibited hemagglutination was considered as an antibody titre. The level of antibody titre on day $13^{\text {th }}$ of the experiment was considered as the primary humoral immune response, while antibody titre on day $20^{\text {th }}$ was considered as the secondary humoral immune response [37]. 


\subsection{Determination of Paw Volume (Delayed Type Hypersensitivity)}

The cellular immune response was assayed by the footpad reaction method. The edema was induced in the right paw of rats by injecting sRBC $\left(0.025 \times 10^{9}\right.$ cells $)$ in the sub-plantar region. The increase in the paw volume after 24 hours (on day 21) was assessed on digital plethysmometer (Pan Lab, Spain). The mean percentage change in paw volume was considered as delayed type of hypersensitivity and as an index of cellmediated immunity. The volume of the left hind paw, injected similarly with phosphate-buffered saline, served as control.

\subsection{Determination of Hematological and Biochemical Parameters}

After fasting for 12 to 16 hours on day $23^{\text {rd }}$ of the experiment, blood was collected from the retro-orbital plexus using heparinized or non-heparinized capillary tubes. One portion of the blood was kept in plain bottles from which serum was collected and stored for biochemical analysis. The other portion was directly subjected for the estimation of various hematological parameters using standard instruments. The levels of hemoglobin ( $\mathrm{Hb})$, red blood cell count (RBC), packed cell volume (PCV), mean corpuscular volume (MCV), mean corpuscular hemoglobin $(\mathrm{MCH})$, mean corpuscular hemoglobin concentration (MCHC) and platelets were analyzed in the blood samples in all experimental groups. Further, the levels of magnesium, blood urea, creatinine, uric acid, calcium, phosphorus, potassium, sodium, and chloride ion concentration were analyzed using a Hematology analyzer (Abbott Model-CD-3700) [38].

\subsection{Determination of Body Weight and Feed Intake}

Body weight and feed consumption of all the animals in various experimental groups were measured daily. Briefly, the weight of daily feed supply and the left-over by the following days were recorded and the difference was taken as the daily feed intake. The average of the feed intake was computed for every three days of the experimental period [39].

\subsection{Clinical Sign and Symptoms}

Animal clinical sign and symptoms were evaluated once daily throughout the experiment in accordance with in-house protocol [40] with slight modification. Animals found in a moribund condition or enduring signs of severe distress were humanely euthanized. Abnormal findings were recorded with the time of onset and disappearance.

\subsection{Measurement of Relative Organ Weight and Histopathology}

At the end of the experiment, rats were dissected and the whole liver, kidneys, hearts, spleens, lungs and uterus were excised, freed of fat, blotted with clean tissue paper, and then weighed. The organ to body weight ratio was determined by comparing the weight of each organ with the final body weight of each rat. Defined samples were placed in $10 \%$ neutral buffered formalin for histopathological examination.

\subsection{Statistical Analysis}

Data were expressed as mean \pm standard error of mean (SEM) and were subjected to Student's $t$-test. Statistical significance was considered at $p \leq 0.05$.

\section{Results and Discussion}

\subsection{Effect of the Test Formulation on Humoral Immune Response}

The results of primary and secondary humoral immune response of the test formulation after the Biofield Treatment are summarized in the Table 1 . The values of primary and secondary antibody titre in the disease control groups were $19.0 \pm 4.67$ and $28.0 \pm 4.00$, respectively. After treatment with the Biofield Energy Treated test formulation, the primary antibody titre was significantly increased $(p<0.01)$, while secondary antibody titre was decreased compared with the disease control group. However, the untreated test formulation did not found any significant effect, so the Biofield Energy Treated test formulation showed a better result in comparison with the untreated test formulation. The values of primary antibody titre in the untreated test formulation was decreased compared with the Biofield Energy Treated test formulation. However, in case of secondary titre, the Biofield Energy Treated test formulation showed lower value $(14.7 \pm 1.33)$ compared with the untreated product test formulation $(18.7 \pm$ 2.67) as well as disease control group.

Table 1. The effect of the test formulation on humoral immune response in female rats.

\begin{tabular}{llll}
\hline S. No & Group & Primary HA titre & Secondary HA titre \\
\hline 1. & Disease control & $19.0 \pm 4.67$ & $28.0 \pm 4.00$ \\
2. & Biofield Treated test formulation & $42.7 \pm 18.78^{* *}$ & $14.7 \pm 1.33$ \\
3. & Untreated test formulation & $1.0 \pm 0.00$ & $18.7 \pm 2.67$ \\
4. & Levamisole & $17.8 \pm 6.49$ & $29.3 \pm 2.67$ \\
\hline
\end{tabular}

Values are expressed as the mean \pm SEM. ${ }^{* *} p<0.01$ compared with the disease control.

The Biofield Energy Treated test formulation group showed a significantly improved primary antibody titre level by $124.7 \%$ compared with the disease control, while the untreated test formulation showed a decreased titre value by $94.74 \%$ compared with the disease control. These results suggest that the Biofield Energy Healing Treatment further improved the immunomodulatory effect of test herbomineral formulation, compared with the untreated test formulation. Overall, the results of the antibody titre suggest that the Biofield Energy Treated test formulation exhibited a potent 
immunomodulatory effect for humoral immunity with improved primary antibody synthesis under inflammatory stimulus. The increased primary antibody titre values in the Biofield Energy Treated test formulation clearly states that Biofield Energy has the capacity to modulate the humoral immunity profile of the test formulation. This could be assumed that after administration of the Biofield Energy Treated test formulation, specific antibodies were produced against antigen, in order to fight against infection, which could improve the overall immunity [41]. However, the humoral immune response activation by the Biofield Energy Treated test formulation could indicate improved responsiveness of the macrophages/B-lymphocytes subsets in these hosts [42].

\subsection{Estimation of Delayed Type Hypersensitivity (Paw Volume)}

The effects of the Biofield Energy Treated test formulation with respect to delayed type hypersensitivity reaction in female rats were measured and are presented in the Figure 1. The results suggest that the mean paw edema volume in $\mathrm{G} 1$, $\mathrm{G} 2, \mathrm{G} 3, \mathrm{G} 4$, and G5 groups were $00.04 \pm 0.01,00.07 \pm 0.02$, $-00.02 \pm 0.02,00.05 \pm 0.04$, and $00.84 \pm 0.04 \mathrm{~mL}$, respectively. However, the Biofield Energy Treated test formulation (G3) showed a significant decrease in paw volume by $128.57 \%$ with respect to the disease control group. Overall, data suggest that the Biofield Energy Treated test formulation exhibited significant immunomodulatory effect on the basis of altered paw volume. It can be assumed that the constituents present in the test formulation are responsible for a delayed type hypersensitivity reaction, however Biofield Energy Healing (The Trivedi Effect ${ }^{\circledR}$ ) Treatment significantly altered the immune response compared with the untreated test formulation.

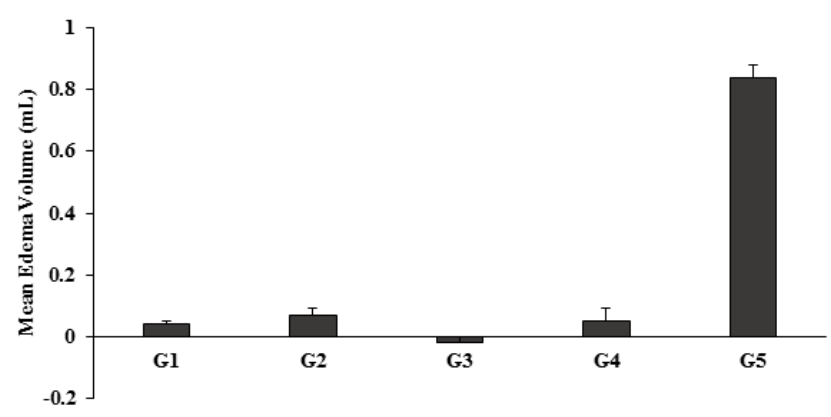

Figure 1. Effect of the test formulation on rat paw volume (delayed-type hypersensitivity). G1: Normal Control; G2: Disease Control: G3: Biofield Energy Treated test formulation; G4: Untreated test formulation; G5: Levamisole. All values are expressed as the mean $\pm \operatorname{SEM}(n=6)$.

\subsection{Effect of the Biofield Energy Treated Herbomineral Formulation on Hematological Parameters}

The results of the Biofield Energy Treated and untreated test formulation administration in experimental animals show an altered hematological profile but did not show any statistically significant difference among different group with respect to the disease control group. The results are summarized in Table 2, which did not show any unfavorable or abnormal hematological tested parameters. The tested hematological parameters such as $\mathrm{RBC}, \mathrm{Hb}, \mathrm{PCV}, \mathrm{MCV}$, $\mathrm{MCH}$, and $\mathrm{MCHC}$ showed slight alteration with respect to the normal and disease control groups. The level of RBC showed a slight increase in all the tested groups compared with the normal control group $(7.72 \pm 0.23)$, but it was not significant. However, the Biofield Energy Treated test formulation showed an increase in RBC count $(9.47 \pm 0.08$ $\left.10^{6} / \mu \mathrm{L}\right)$ compared with the untreated test formulation $(9.17 \pm$ $0.2110^{6} / \mu \mathrm{L}$ ). The RBC count was improved by $7.24 \%$ and $3.85 \%$ in the Biofield Energy Treated and untreated test formulation, respectively with respect to the disease control group. However, it was reported in the animal study that ashwagandha root extract prevents myelosuppression in mice with improved hematological parameters such as $\mathrm{RBC}, \mathrm{Hb}$, WBC, and platelet count [43]. The study results are well corroborated with respect to the ashwagandha extract and other test formulation ingredients, further the Biofield Energy Treatment showed an improved efficacy of the test formulation with respect to the hematological parameters.

Various other hematological parameters such as $\mathrm{Hb}, \mathrm{PCV}$, $\mathrm{MCV}, \mathrm{MCH}$, and $\mathrm{MCHC}$ showed slight alterations with respect to the normal and disease control groups. MCHC is defined as the derived value from the $\mathrm{Hb}$ measurement and the hematocrit. As, $\mathrm{Hb}$ denotes the amount of hemoglobin in a volume of blood, while hematocrit is defined as the ratio of the volume of red cells to the volume of whole blood. MCHC is considered as standard part of the complete blood count. The present experimental results showed a significant increase in the values of MCHC by $138.09 \%$, while the untreated test formulation was not able to improve the MCHC percentage compared with the disease control group. Similarly, the platelet count in the normal control group was reported as $1047.50 \pm$ 113.10 thousand $/ \mathrm{mm}^{3}$, which was decreased to $760.67 \pm 67.37$ thousand $/ \mathrm{mm}^{3}$ in the disease control group. However, the Biofield Energy Treated test formulation showed the platelet level was increased by $17.70 \% \quad(895.33 \pm 171.90$ thousand $/ \mathrm{mm}^{3}$ ) compared with disease control values. Thus, it can be concluded that the test formulation showed overall improved hematological parameters such as RBC, MCHC, and platelet count. Scientific literature suggests that ashwagandha root extract has shown improved platelet counts in animals [44]. The experimental results were well supported with the literature data, as the new herbomineral proprietary formulation contains ashwagandha root extract along with important minerals. Ashwagandha root extract was reported without any toxic effect on the human erythrocytes [45], similar observations were reported in this experiment as no hemolysis was reported due to the test formulation at the tested concentration with respect to the normal control and disease control group. The minerals present in the test formulation were reported with improved hematological parameters and regarded as safe with good therapeutic effect [46].

It can be suggested that the Biofield Energy Treated test formulation can be used to improve the $\mathrm{RBC}, \mathrm{MCHC}$, and platelet count that proved as better efficacy compared with 
the untreated formulation.

Table 2. Assessment of Hematology parameters after treatment with the test formulation in female rats.

\begin{tabular}{|c|c|c|c|c|}
\hline Group (G) & $\mathrm{RBC}\left(10^{6} / \mu \mathrm{L}\right)$ & Hb (gm/dL) & PCV (\%) & $\operatorname{MCV}(\mathbf{f l})$ \\
\hline 1 & $7.72 \pm 0.23$ & $14.90 \pm 0.55$ & $43.52 \pm 1.42$ & $56.40 \pm 1.11$ \\
\hline 2 & $8.83 \pm 0.22$ & $17.00 \pm 0.25$ & $57.73 \pm 0.86$ & $62.03 \pm 0.85$ \\
\hline 3 & $9.47 \pm 0.08$ & $16.88 \pm 0.18$ & $59.73 \pm 0.55$ & $63.12 \pm 0.48$ \\
\hline 4 & $9.17 \pm 0.21$ & $16.22 \pm 0.39$ & $56.40 \pm 1.09$ & $61.17 \pm 0.80$ \\
\hline 5 & $9.65 \pm 0.11$ & $16.83 \pm 0.23$ & $58.88 \pm 0.62$ & $61.18 \pm 0.71$ \\
\hline
\end{tabular}

Table 2. Continued.

\begin{tabular}{llll}
\hline Group (G) & MCH (pg) & MCHC (\%) & Platelet Count (thousand/mm $\left.{ }^{3}\right)$ \\
\hline 1 & $19.28 \pm 0.38$ & $34.23 \pm 0.25$ & RDW-CV \\
2 & $18.18 \pm 0.24$ & $29.35 \pm 0.21$ & $1047.50 \pm 113.10$ \\
3 & $17.87 \pm 0.20$ & $69.88 \pm 14.62^{*}$ & $760.67 \pm 67.37$ \\
4 & $17.52 \pm 0.19$ & $28.70 \pm 0.18$ & $895.33 \pm 171.90$ \\
5 & $17.38 \pm 0.22$ & $28.48 \pm 0.09$ & $1060.83 \pm 113.17$ \\
\hline
\end{tabular}

All values are presented as mean \pm SEM $(n=6)$. G represents as group; G1: Normal control; G2: Disease control (Pyrogallol); G3: Biofield Energy Treated test formulation; G4: Untreated test formulation; G5: Reference compound (Levamisole). ${ }^{*} p<0.05$ compared to the disease control. Hb: Hemoglobin; RBC: Red blood count; PCV: Packed cell volume; MCV: Mean corpuscular volume; MCH: Mean corpuscular hemoglobin; MCHC: Mean corpuscular hemoglobin concentration; Red cell distribution width and volume (RDW-CV).

\subsection{Effect of the Biofield Energy Treated Test Formulation on Serum Biochemistry}

The effect of the Biofield Energy Treated test formulation with respect to the biochemical parameters was summarized in the Table 3. The biochemical parameters were studied and compared with respect to magnesium level, blood urea, creatinine, uric acid, calcium, phosphorus, sodium, potassium, and chloride ion concentrations. The results suggest that the values of blood urea was increased by $42.5 \%$ (56.10 \pm 6.36 $\mathrm{mg} / \mathrm{dL}$ ) in the disease control group, while in the Biofield Energy Treated test formulation group further decreased value by $10.90 \%$ was observed compared with the disease control group. The level of potassium ions in the Biofield Energy Treated test formulation group showed an increased level as $11.23 \pm 4.25 \mathrm{mEq} / \mathrm{L}$ compared with the disease control $(10.02 \pm 1.51 \mathrm{mEq} / \mathrm{L})$ and normal control group $(5.32$ $\pm 0.11 \mathrm{mEq} / \mathrm{L})$. Similarly, the magnesium level was increased by $13.29 \%$ in the Biofield Energy Treated test formulation group $(4.09 \pm 0.28 \mathrm{mg} / \mathrm{dL})$ compared with the disease control group $(3.61 \pm 0.16 \mathrm{mg} / \mathrm{dL})$. The level of phosphorus was increased by $6.28 \%(12.68 \pm 1.62 \mathrm{mg} / \mathrm{dL})$ in the Biofield Energy Treated test formulation group compared with the disease control group (11.93 $\pm 0.90 \mathrm{mg} / \mathrm{dL})$. However, the other tested biochemical parameters were also reported with altered values compared with the normal and disease control groups. However, overall results suggest that the Biofield Energy Treated test formulation group showed altered biochemical parameters after oral administration of test formulation in female rats compared with the disease control group. This suggest that the test formulation was nontoxic with respect to the hematological parameters, as literature suggests that the constituents of test formulation like ashwagandha root extract did not find any serious toxicity or side effects and thus can be safely used for any acute and chronic treatment [47]. Each minerals used in the test formulation was already reported to be safe and beneficial, so it can be concluded that the Biofield Energy Treated test formulation showed better improved hematological and biochemical profiles compared with the untreated test formulation and found to be safe in all aspect.

Table 3. Estimation of biochemical parameters after treatment with the test formulation in female rats.

\begin{tabular}{|c|c|c|c|c|}
\hline Group (G) & Magnesium (mg/dL) & Blood Urea (mg/dL) & Creatinine (mg/dL) & Uric Acid (mg/dL) \\
\hline 1 & $2.61 \pm 0.08$ & $39.37 \pm 2.25$ & $0.60 \pm 0.00$ & $2.85 \pm 0.37$ \\
\hline 2 & $3.61 \pm 0.16$ & $56.10 \pm 6.36$ & $0.38 \pm 0.06$ & $9.05 \pm 1.91$ \\
\hline 3 & $4.09 \pm 0.28$ & $49.98 \pm 3.69$ & $0.40 \pm 0.09$ & $10.77 \pm 3.59$ \\
\hline 4 & $4.27 \pm 0.28$ & $57.03 \pm 5.07$ & $0.48 \pm 0.09$ & $13.18 \pm 1.26$ \\
\hline 5 & $3.35 \pm 0.17$ & $45.97 \pm 4.95$ & $0.45 \pm 0.07$ & $7.15 \pm 2.33$ \\
\hline
\end{tabular}

Table 3. Continued.

\begin{tabular}{lllll}
\hline Group (G) & Calcium (mg/dL) & Phosphorus (mg/dL) & $\mathbf{K}^{+}(\mathbf{m E q} / \mathbf{L})$ & $\mathbf{N a}^{+}(\mathbf{m E q} / \mathbf{L})$ \\
\hline 1 & $10.02 \pm 0.14$ & $8.00 \pm 0.20$ & $5.15 \pm 0.09$ & $142.37 \pm 7.48$ \\
2 & $11.48 \pm 1.12$ & $11.93 \pm 0.90$ & $10.02 \pm 1.51$ & $143.85 \pm 2.84$ \\
3 & $9.95 \pm 0.41$ & $12.68 \pm 1.62$ & $11.23 \pm 4.25$ & $138.00 \pm 6.48$ \\
4 & $9.82 \pm 0.49$ & $14.20 \pm 0.70$ & $15.83 \pm 2.54$ & $131.00 \pm 1.06$ \\
5 & $10.32 \pm 0.26$ & $10.77 \pm 1.10$ & $9.82 \pm 2.27$ & $107.33 \pm 2.91$ \\
\hline
\end{tabular}

All values are presented as mean \pm SEM $(n=6)$. G represents as group; G1: Normal control; G2: Disease control (Pyrogallol); G3: Biofield Energy Treated test formulation; G4: Untreated test formulation; and G5: Reference compound (Levamisole). 


\subsection{Effect of the Test Formulation on Body Weight and Organ to Body Weight Ratio}

The effect of the Biofield Energy Treated test formulation administration on animal weight parameters of female rats were analyzed and presented in Table 4 . The results reflect the change in body weight, as final weights were increased among all the tested groups. The mean body weight percentage difference in the Biofield Energy Treated test formulation group and untreated test formulation group did not have any significant difference compared with the disease control group.

The results suggest that there was no significant change throughout the experimental period in relative organ weight parameters such as in liver, kidney, lungs, spleen, heart, ovaries, uterus, and brain with respect to the normal and disease control groups (Table 4). The results of relative organ weight suggest that in the disease control group, a slight increase was recorded, while after treatment with the Biofield Energy Treated test formulation, the organ weight reached normal level similar to the control group.

Table 4. Effect of the test formulation on organ weight parameters of female rats.

\begin{tabular}{lllll}
\hline Relative weight (\%) & G1 & G2 & G3 & G4 \\
\hline Liver & $3.11 \pm 0.13$ & $3.28 \pm 0.12$ & $3.50 \pm 0.14$ & $3.54 \pm 0.12$ \\
Kidney & $0.75 \pm 0.03$ & $0.83 \pm 0.03$ & $0.76 \pm 0.03$ & $0.79 \pm 0.03$ \\
Lungs & $0.64 \pm 0.02$ & $0.75 \pm 0.06$ & $0.67 \pm 0.04$ & $0.65 \pm 0.05$ \\
Spleen & $0.31 \pm 0.01$ & $0.34 \pm 0.02$ & $0.35 \pm 0.02$ & $0.34 \pm 0.02$ \\
Heart & $0.40 \pm 0.02$ & $0.43 \pm 0.03$ & $0.45 \pm 0.05$ & $0.41 \pm 0.03$ \\
Brain & $0.84 \pm 0.05$ & $0.86 \pm 0.05$ & $0.84 \pm 0.05$ & 0.14 \\
Eyes & $0.11 \pm 0.01$ & $0.13 \pm 0.01$ & $0.12 \pm 0.01$ & $0.03 \pm 0.03$ \\
Ovary & $0.08 \pm 0.01$ & $0.10 \pm 0.01$ & $0.10 \pm 0.01$ & $0.03 \pm 0.01$ \\
Uterus & $0.28 \pm 0.03$ & $0.42 \pm 0.05$ & $0.36 \pm 0.03$ & 0.03 \\
Whole intestine & $6.25 \pm 0.20$ & $5.88 \pm 0.21$ & $7.70 \pm 0.21$ & $0.38 \pm 0.07$ \\
\hline
\end{tabular}

Values are presented as mean \pm SEM $(n=6)$. G represents as group; G1: Normal control; G2: Disease control (Pyrogallol); G3: Biofield Energy Treated test formulation; G4: Untreated test formulation; and G5: Reference compound (Levamisole).

The increase in organ weight after any treatment or exposure to any substance could be correlated to the toxicological implications. If organ weights increase, it can be correlated with hypertrophy, while atrophy in the case of decreased organ weight conditions, while organ to body weight ratio is considered as a useful index for the identification of toxicological implications such as swelling, atrophy or hypertrophy [46]. However, the Biofield Energy Treated test formulation did not show any unfavorable interaction or inflammation/cellular constriction with tested organs which suggests the safe nature of the test herbomineral formulation. In this study, no significant change in an organ or body weight or unfavorable interactions has been found during the experimental period, which supports the nontoxic nature of the Biofield Energy Treated test formulation.

\subsection{Effect of the Biofield Energy Treated Test Formulation on Feed Intake}

The results of the animal feed intake measurement are shown in the Figure 2. The result suggests no treatment related change was observed throughout the experiment compared with the normal control group. The animals in the disease control group showed a slight decrease in mean feed intake in the Biofield Energy Treated test formulation group $(15.44 \pm 6.77 \mathrm{gm})$ compared with the normal (17.20 \pm 8.29 gm) and disease control group $(16.78 \pm 6.84$ gm). Further, the levamisole group also showed a slight decrease in mean feed intake $(15.79 \pm 13.11 \mathrm{gm})$ compared with the normal and disease control groups. Overall, the results reflect no significant change in feed intake in animals after treatment with the Biofield Energy Treated and untreated test formulation, which depicts that the product is quite safe at the selected doses. The results suggest that the Biofield Energy Treated or untreated test formulation, did not have any concern with the appetite of the animals and could not relate to any consequential effects on their performances, as also reflected with no change in body weight parameters.

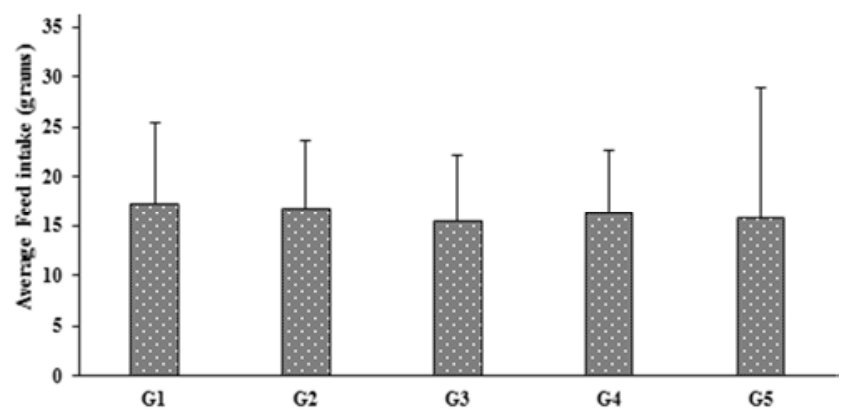

Figure 2. The effect of the test formulation on feed intake of female rats. All values are presented as mean $\pm \operatorname{SEM}(n=6)$. G represents as group; G1: Normal control; G2: Disease control (Pyrogallol); G3: Biofield Energy Treated test formulation; G4: Untreated test formulation; G5: Reference compound (Levamisole).

\subsection{Histopathological Study}

Histopathological analysis of kidney, brain, liver, heart, lungs, uterus and cervix were performed and the results suggest no toxicological changes with respect to treatment of all the experimental animals as compared with the normal and disease control group. Liver histopathology data suggest only minimal severity was observed in disease control, while test formulation treated groups showed centrizonal necrosis, 
while the rest of the histopathology was reported as normal without having any severe lesions. On the basis of severity and incidence, histopathological findings suggest that the toxicological consideration might be irrelevant and incidental in nature, and was not related to the treatment. The detailed classification and severity score was summarized in Table 5, and microscopic organ sections are shown in Figure 3.

Table 5. Histopathological finding after treatment with the test formulation in female rats.

\begin{tabular}{|c|c|c|c|c|c|c|c|}
\hline \multirow{2}{*}{ S. No. } & \multirow{2}{*}{ Organs and Findings } & \multirow{2}{*}{ Severity } & \multicolumn{5}{|c|}{ Experimental Groups } \\
\hline & & & G1 & G2 & G3 & G4 & G5 \\
\hline 1. & Kidney & - & $0 / 6$ & $0 / 6$ & $0 / 6$ & $0 / 6$ & $0 / 6$ \\
\hline 2. & Brain & - & $0 / 6$ & $0 / 6$ & $0 / 6$ & $0 / 6$ & $0 / 6$ \\
\hline \multirow[t]{4}{*}{3.} & Liver & - & & & & & \\
\hline & -Hepatocytic vacuolation & & $0 / 6$ & $0 / 6$ & $0 / 6$ & $0 / 6$ & $0 / 6$ \\
\hline & -Centrizonal & 1 & $0 / 6$ & $1 / 6$ & $4 / 6$ & $4 / 6$ & $0 / 6$ \\
\hline & -Scattered & & $2 / 6$ & $0 / 6$ & $0 / 6$ & $0 / 6$ & $0 / 6$ \\
\hline 5. & Lungs & - & $0 / 6$ & $0 / 6$ & $0 / 6$ & $0 / 6$ & $0 / 6$ \\
\hline 6. & Uterus & - & $0 / 6$ & $0 / 6$ & $0 / 6$ & $0 / 6$ & $0 / 6$ \\
\hline 7. & Cervix & - & $0 / 6$ & $0 / 6$ & $0 / 6$ & $0 / 6$ & $0 / 6$ \\
\hline
\end{tabular}

'-'denotes the absence of indicative grading; 1 represents minimal severity; 0/6 denotes zero severity out of six animals. G represents as group; G1: Normal control; G2: Disease control (Pyrogallol); G3: Biofield Energy Treated test formulation; G4: Untreated test formulation; G5: Reference compound (Levamisole).

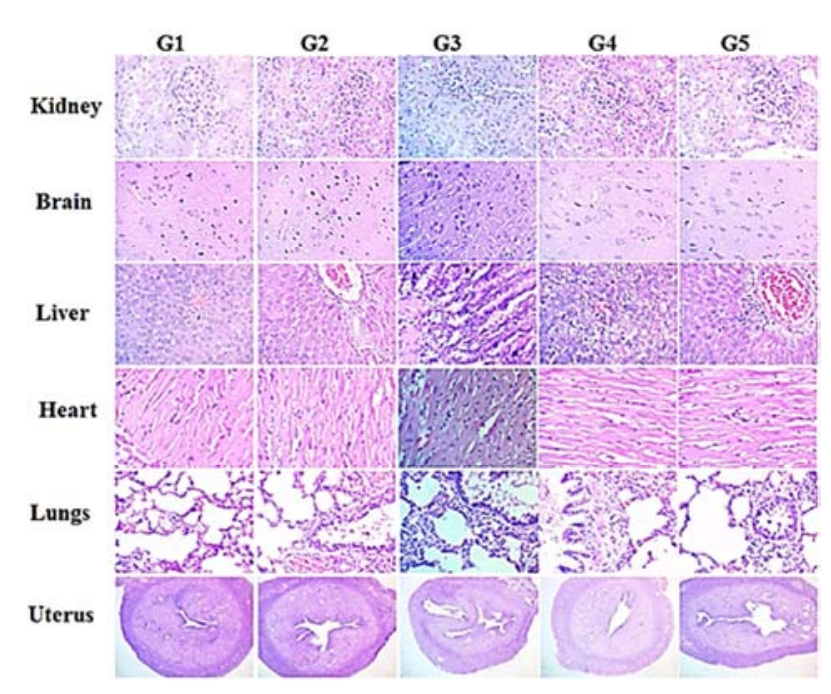

Figure 3. Histopathological cross sections of major organs in female rats after treatment with the test formulation. G represents as group; G1: Normal control; G2: Disease control (Pyrogallol); G3: Biofield Energy Treated test formulation; G4: Untreated test formulation; G5: Reference compound (Levamisole).

Biofield Energy Treatment is a kind of electromagnetic field or radiation therapy by Biofield Energy Healers, as reported that can improve the overall quality of life such as in case of cancer [48]. Biofield Energy migrates through the enviornmantal medium and rapidly propagates throughout the organism after treatment with The Trivedi Effect ${ }^{\circledR}$ Biofield Energy Healing. Hence, it might be suggested that Biofield Energy Treatment might improve the internal interferance of molecules used in the natural proprietary herbomineral formulation, which showed an imporved antiinflammatory and immunomodulatory activities compared with the untreated test formulation. Complementary and Alternate Medicine (CAM) has reported several advantages over the current preferred treatment approach $[49,50]$. The important minerals required to boost-up the immune system along with the overall effective herbal extract of ashwagandha root can be defined as the powerful source of new herbomineral product, which could prooved better results compared with the existing herbal products or conventaional medicines.

\section{Conclusions}

Overall, it can be concluded that the newly formulated herbomineral test formulation after Biofield Energy Treatment by renowned Biofield Energy Healers showed an improved immunomodulatory effect, as suggested with increased antibody titre values. The Biofield Energy Treated test formulation group (G3) animals showed a significant increased primary antibody titre by $124.7 \%$ compared with the disease control group, indicating that the results were much better than the untreated test formulation. The results given of a delayed type hypersensitivity response suggest that paw volume was significantly decreased by $128.57 \%$ in the G3 group animals compared with the disease control group. Further, the G3 group animals showed improved hematology parameters RBC (7.24\%), MCHC (138.09\%) and platelets $(17.70 \%)$ compared with the disease control. However, the serum biochemistry analysis in the Biofield Energy Treated herbomineral formulation group (G3) animals showed a decreased level of blood urea by $10.90 \%$, while the magnesium and phosphorus level were increased by $13.29 \%$ and $6.28 \%$, respectively compared with the disease control group. The Biofield Energy Treated and untreated test formulations did not find any toxic effects as reported without any sign of mortality, weight parameters, and feed intake during the course of the experiment. The test formulation was found to be safe and did not affect the animal appetite or performance throughout the experimental period. No treatment related gross lesion or microscopic findings were observed in any of the isolated rat organs from the treatment groups, and no significant change in the organ to body weight ratio was found compared with the disease 
control group. Histopathological findings did not suggest any sign of severity after treatment at all the tested doses.

Therefore, the Trivedi Effect ${ }^{\mathbb{R}}$-Biofield Energy Healing administered remotely by the eighteen Biofield Energy Healers enhanced the herbomineral test formulation's antiinflammatory and immunomodulatory properties without any side effects, and can be used as a herbomineral product to improve the overall health. Thus, the Biofield Energy Treated test formulation may act as an effective anti-inflammatory and immunomodulatory product, and it can be used as a Complementary and Alternative Medicine (CAM) with a safe therapeutic index for various autoimmune disorders such as Lupus, Systemic Lupus Erythematosus, Fibromyalgia, Addison Disease, Hashimoto Thyroiditis, Celiac Disease (gluten-sensitive enteropathy), Multiple Sclerosis, Dermatomyositis, Graves' Disease, Myasthenia Gravis, Pernicious Anemia, Aplastic Anemia, Scleroderma, Psoriasis, Rheumatoid Arthritis, Reactive Arthritis, Type 1 Diabetes, Sjogren Syndrome, Crohn's Disease, Vasculitis, Vitiligo, Chronic Fatigue Syndrome and Alopecia Areata, as well as inflammatory disorders such as Irritable Bowel Syndrome (IBS), Asthma, Ulcerative Colitis, Alzheimer's Disease, Parkinson's Disease, Atherosclerosis, Dermatitis, Hepatitis, and Diverticulitis. Further, the Biofield Energy Healing Treated test formulation can also be used in the prevention of immune-mediated tissue damage in cases of organ transplants (for example heart transplants, kidney transplants and liver transplants), for anti-aging, stress prevention and management, and in the improvement of overall health and quality of life.

\section{Acknowledgements}

The authors are grateful to Dabur Research Foundation, Trivedi Science, Trivedi Global, Inc., and Trivedi Master Wellness for their support throughout the work.

\section{References}

[1] Ziauddin M, Phansalkar N, Patki P, Diwanay S, Patwardhan B (1996) Studies on immunomodulatory effects of ashwagandha. J Ethnopharmacol 50: 69-76.

[2] De P, Dasgupta SC, Gomes A (1998) Immunopotentiating activity of immue-21; A polyherbal product. Indian J Pharmacol 30: 163-168.

[3] Huai H (2010) Ethnomedicinal analysis of toxic plants from five ethnic groups in China. Ethnobot Res Appl 8: 169-179.

[4] Modak M, Dixit P, Londhe J, Ghaskadbi S, Devasagayam TPA (2007) Indian herbs and herbal drugs used for the treatment of diabetes. J Clin Biochem Nutr 40: 163-173.

[5] Girdhari L, Rana A (2007) Withania somnifera (ashwagandha): A review. Pharmacognosy Rev 1: 129-136.

[6] Owais M, Sharad KS, Shehbaz A, Saleemuddin M (2005) Antibacterial efficacy of Withania somnifera (Ashwagandha) an indigenous medicinal plant against experimental murine salmonellosis. Phytomed 12: 229-235.
[7] Davis L, Kuttan G (2000) Immunomodulatory activity of Withania somnifera. J Ethnopharmacol 71: 193-200.

[8] Singh N, Bhalla M, de Jager P, Gilca M (2011) An overview on ashwagandha: A Rasayana (Rejuvenator) of Ayurveda. Afr J Tradit Complement Altern Med 8: 208-213.

[9] Lukác N, Massányi P (2007) Effects of trace elements on the immune system. Epidemiol Mikrobiol Imunol 56: 3-9.

[10] Galland L (1988) Magnesium and immune function: an overview. Magnesium 7: 290-299.

[11] Mazumder PM, Pattnayak S, Parvani H, Sasmal D, Rathinavelusamy P (2012) Evaluation of immunomodulatory activity of Glycyrhiza glabra L roots in combination with zing. Asian Pac J Trop Biomed 2: S15-S20.

[12] Lutgendorf SK, Mullen-Houser E, Russell D, Degeest K, Jacobson G, Hart L, Bender D, Anderson B, Buekers TE, Goodheart MJ, Antoni MH, Sood AK, Lubaroff DM (2010) Preservation of immune function in cervical cancer patients during chemoradiation using a novel integrative approach. Brain Behav Immun 24: 1231-1240.

[13] Ironson G, Field T, Scafidi F (1996) Massage therapy is associated with enhancement of the immune system's cytotoxic capacity. Int J Neurosci 84: 205-217.

[14] Jain S, Hammerschlag R, Mills P, Cohen L, Krieger R, Vieten C, Lutgendorf S (2015) Clinical studies of biofield therapies: Summary, methodological challenges, and recommendations. Glob Adv Health Med 4: 58-66.

[15] Rubik B (2002) The biofield hypothesis: Its biophysical basis and role in medicine. J Altern Complement Med 8: 703-717.

[16] Trivedi MK, Patil S, Shettigar H, Mondal SC, Jana S (2015) The potential impact of biofield treatment on human brain tumor cells: A time-lapse video microscopy. J Integr Oncol 4: 141.

[17] Trivedi MK, Patil S, Shettigar H, Gangwar M, Jana S (2015) In vitro evaluation of biofield treatment on cancer biomarkers involved in endometrial and prostate cancer cell lines. J Cancer Sci Ther 7: 253-257.

[18] Trivedi MK, Patil S, Shettigar H, Mondal SC, Jana S (2015) In vitro evaluation of biofield treatment on Enterobacter cloacae: Impact on antimicrobial susceptibility and biotype. J Bacteriol Parasitol 6: 241.

[19] Trivedi MK, Patil S, Shettigar H, Mondal SC, Jana S (2015) Evaluation of biofield modality on viral load of hepatitis B and C Viruses. J Antivir Antiretrovir 7: 083-088.

[20] Trivedi MK, Patil S, Shettigar H, Mondal SC, Jana S (2015) An impact of biofield treatment: Antimycobacterial susceptibility potential using BACTEC 460/MGIT-TB System. Mycobact Dis 5: 189.

[21] Trivedi MK, Branton A, Trivedi D, Nayak G, Mondal SC, Jana S (2015) Antimicrobial sensitivity, biochemical characteristics and biotyping of Staphylococcus saprophyticus: An impact of biofield energy treatment. J Women's Health Care 4: 271.

[22] Trivedi MK, Branton A, Trivedi D, Nayak G, Mondal SC, Jana S (2015) Evaluation of antibiogram, genotype and phylogenetic analysis of biofield treated Nocardia otitidis. Biol Syst Open Access 4: 143. 
[23] Trivedi MK, Branton A, Trivedi D, Nayak G, Charan S, Jana S (2015) Phenotyping and 16S rDNA analysis after biofield treatment on Citrobacter braakii: A urinary pathogen. J Clin Med Genom 3: 129.

[24] Trivedi MK, Patil S, Shettigar H, Bairwa K, Jana S (2015) Spectroscopic characterization of chloramphenicol and tetracycline: An impact of biofield. Pharm Anal Acta 6: 395.

[25] Trivedi MK, Patil S, Shettigar H, Bairwa K, Jana S (2015) Spectroscopic characterization of biofield treated metronidazole and tinidazole. Med Chem 5: 340-344.

[26] Trivedi MK, Patil S, Shettigar H, Bairwa K, Jana S (2015) Effect of biofield treatment on spectral properties of paracetamol and piroxicam. Chem Sci J 6: 98.

[27] Trivedi MK, Branton A, Trivedi D, Shettigar H, Bairwa K, Jana S (2015) Fourier transform infrared and ultravioletvisible spectroscopic characterization of biofield treated salicylic acid and sparfloxacin. Nat Prod Chem Res 3: 186.

[28] Trivedi MK, Branton A, Trivedi D, Nayak G, Gangwar M, Jana S (2016) Molecular analysis of biofield treated eggplant and watermelon crops. Adv Crop Sci Tech 4: 208.

[29] Trivedi MK, Branton A, Trivedi D, Nayak G, Mondal SC, Jana S (2015) Morphological characterization, quality, yield and DNA fingerprinting of biofield energy treated alphonso mango (Mangifera indica L.). Journal of Food and Nutrition Sciences 3: 245-250.

[30] Trivedi MK, Branton A, Trivedi D, Nayak G, Mondal SC, Jana S (2015) Evaluation of plant growth, yield and yield attributes of biofield energy treated mustard (Brassica juncea) and chick pea (Cicer arietinum) seeds. Agriculture, Forestry and Fisheries 4: 291-295.

[31] Trivedi MK, Branton A, Trivedi D, Nayak G, Mondal SC, Jana S (2015) Evaluation of plant growth regulator, immunity and DNA fingerprinting of biofield energy treated mustard seeds (Brassica juncea). Agriculture, Forestry and Fisheries 4: 269-274.

[32] Trivedi MK, Tallapragada RM, Branton A, Trivedi D, Nayak G, Jana S (2015) Characterization of physical and structural properties of aluminum carbide powder: Impact of biofield treatment. J Aeronaut Aerospace Eng 4: 142.

[33] Trivedi MK, Nayak G, Patil S, Tallapragada RM, Latiyal O, Jana S (2015) Impact of biofield treatment on atomic and structural characteristics of barium titanate powder. Ind Eng Manage 4: 166.

[34] Trivedi MK, Patil S, Nayak G, Jana S, Latiyal O (2015) Influence of biofield treatment on physical, structural and spectral properties of boron nitride. J Material Sci Eng 4: 181.

[35] Trivedi MK, Nayak G, Patil S, Tallapragada RM, Latiyal O, Jana S (2015) Characterization of physical and structural properties of brass powder after biofield treatment. J Powder Metall Min 4: 134.

[36] Ladics GS (2007) Primary immune response to sheep red blood cells (SRBC) as the conventional T-cell dependent antibody response (TDAR) test. J Immunotoxicol 4: 149-52.
[37] Joharapurkar AA, Zambad SP, Wanjari MM, Umathe SN (2003) In vivo evaluation of antioxidant activity of alcoholic extract of Rubia cordifolia Linn. And its influence on ethanolinduced immunosuppression. Indian J Pharmacol 35: 232-236.

[38] Feldman BF, Zinkl JG, Jain VC (2000) Laboratory techniques for avian hematology," in Schalm's Veterinary Hematology, ( $5^{\text {th }}$ edn) Lippincott Williams \& Wilkins, Toronto, Canada.

[39] Chanda S, Dave R, Kaneria M, Shukla V (2012) Acute oral toxicity of Polyalthia longifolia var. pendula leaf extract in wistar albino rats. Pharmaceutical Biol 50: 1408-1415.

[40] OECD (1992) OECD Guideline for Testing of Chemicals, vol. 420, Organization for Economic Cooperation and Development, Paris, France.

[41] Dean JH, Murray MJ (1993) Toxic responses of the immune system. In Casarett and Doull's Toxicology. $\left(4^{\text {th }}\right.$ edn $)$, Amdur MO, Doull J, Klaassen CD. New York: McGraw-Hill, 282286.

[42] Furr SR (2004) Fundamentals of Immunology. In: Pharmaceutical Microbiology, W. B. Hugo and A. D. Russel, $\left(6^{\text {th }}\right.$ edn $)$, Blackwell Science Ltd., Oxford.

[43] Kumar S, Gupta P, Sharma S, Kumar D (2011) A review on immunostimulatory plants. J Chin Integr Med 9: 117-128.

[44] Agarwal R, Diwanay S, Patki P, Patwardhan B (1999) Studies on immunomodulatory activity of Withania somnifera (ashwagandha) extracts in experimental immune inflammation. J Ethnopharmacol 67: 27-35.

[45] Owais M, Sharad KS, Shehbaz A, Saleemuddin M (2005) Antibacterial efficacy of Withania somnifera (ashwagandha) an indigenous medicinal plant against experimental murine salmonellosis. Phytomedicine 12: 229-235.

[46] Amresh GR, Singh PN, Rao CV (2008) Toxicological screening of traditional medicine Laghupatha (Cissampelos pareira) in experimental animals. J Ethnopharmacol 116: 454460.

[47] Kulkarni SK, Dhir A (2008) Withania somnifera: An Indian ginseng. Prog Neuropsychopharmacol Biol Psychiatry 32: 1093-1105.

[48] Gronowicz G, Secor ER, Flynn JR, Jellison ER, Kuhn LT (2015) Therapeutic touch has significant effects on mouse breast cancer metastasis and immune responses but not primary tumor size. Evid Based Complement Alternat Med 2015: 926565.

[49] Clarke TC, Black LI, Stussman BJ, Barnes PM, Nahin RL (2015) Trends in the use of complementary health approaches among adults: Unites States, 2002-2012. National health statistics reports; no 79. Hyattsville, MD: National Center for Health Statistics.

[50] Eisenberg DM, Davis RB, Ettner SL, Appel S, Wilkey S, Van Rompay M, Kessler RC (1998) Trends in alternative medicine use in the United States, 1990-1997: Results of a follow-up national survey. JAMA 280: 1569-1575. 